\title{
Pemanfaat Sosial Media Youtube Sebagai Media Pembelajaran Bahasa Indonesia DI Perguruan Tinggi
}

\author{
Muhammad Yusi Kamhar ${ }^{1}$, Erma Lestari \\ Pendidikan Matematika FIP Universitas Tribhuwana Tunggadewi \\ E-mail-1: yusi.unitri2017@gmail.com
}

\begin{abstract}
Abstrak
Mata kuliah Bahasa Indonesia berperan terhadap perkembangan sosial, intelektual, dan emosional peserta didik. Mata kuliah bahasa Indonesia diharapkan dapat membantu peserta didik untuk membentuk karakter berbahasa sopan, budaya, mengemukakan pendapat dengan baik, dan meningkatkan kemampuan analisis serta imajinatif. Mata kuliah bahasa Indonesia memiliki problematika terbesar, yaitu kurangnya kreativitas metode dan media ajar sehingga membuat peserta didik jenuh mengikuti proses belajar-mengajar di kelas. Penulis mencoba mengungkapkan perlu adanya pembaharuhan media ajar. Media ajar yang digunakan harus dekat dengan kehidupan sehari-hari peserta didik seperti media sosial khususnya YouTube. Belajar dan ngobrol santai dengan keluarga sering menggunakan sosial media. Era globalisasi dan teknologi sosial media dari kehidupan masyarakat modern. Kebiasaan menggunakan media sosial ini secara tidak langsung dapat menjadikan penggunanya mengakses informasi dan mempelajari informasi yang diaksesnya, sehingga tidak heran jika saat ini perekembangan dan penyebaran bahasa berjalan dengan sangat cepat. Era digital ini menandai bahwa saat ini masyarakat sudah menjadi masyarakat yang modern. Sosial media yang digunakan pada penelitian ini, yaitu YouTube.
\end{abstract}

Kata kunci: Bahasa Indonesia, media pembelajaran, sosial media.

\section{PENDAHULUAN}

Bahasa Indonesia berperan penting dalam perkembangan sosial, intelektual, dan emosional peserta didik. Pembelajaran bahasa Indonesia diharapkan dapat membantu peserta didik untuk membentuk karakter berbahasa sopan, budaya, mengemukakan pendapat dengan baik, dan meningkatkan kemampuan analisis serta imajinatif. Pembelajaran bahasa Indonesia memiliki problematika terbesar, yaitu kurangnya kreativitas metode dan media ajar sehingga membuat peserta didik jenuh mengikuti proses belajar-mengajar di kelas. Pembelajaran Bahasa Indonesia diarahkan untuk meningkatkan kemampuan mahasiswa berkomunikasi dengan baik, benar, dan tepat secara tertulis maupun lisan. Pembelajaran bahasa Indonesia juga diharapkan menumbuhkan apresiasi terhadap hasil karya sastra Indonesia. Kriteria bahasa yang baik dan benar menurut Sugono (2009), yaitu baik dan ketepatan memilih kata berdasarkan situasi secara lisan dan tulisan. 
Anggapan mahasiswa pada umumnya mata kuliah bahasa Indonesia merupakan mata kuliah yang gampang saja. Bahkan, sebagian mahasiswa menganggap remeh mata kuliah Bahasa Indonesia. Mahasiswa menganggap jika pelajaran bahasa Indonesia umumnya hanya fokus pada tata bahasa dan penulisan. Padahal jika dilihat pada kenyataannya saat masa sekolah SD, SMP, SMA/MAN/MA ketikan ujian nasional banyak siswa yang tidak lulus pada pelajaran Bahasa Indonesia. Beberapa bukti banyak siswa yang tidak lulus dapat disimpulkan bahwa pelajaran bahasa Indonesia dikategorikan sulit.

Hakikatnya, pembelajaran bahasa Indonesia di perguruan tinggi ditujukan untuk menumbuhkan kepedulian mahasiswa, dosen, tata usaha, dan pihakpihak universitas terhadap keberadaan bahasa Indonesia sebagai alat komunikasi dan sebagai alat pemersatu bangsa ini. Kepedulian itu pada gilirannya diharapkan akan meningkatkan sikap positif terhadap bahasa Indonesia baik sebagai lambang identitas, kebanggaan bangsa, serta pembangkit rasa solidaritas kemanusiaan maupun sebagai sarana memperkokoh persatuan dan kesatuan bangsa.

Masyarakat Indonesia tidak lepas dari smartphone khususnya kalangan remaja. Apa yang menyibukkan mereka? Tidak lain adalah dunia online, dari media sosial seperti Facebook, Twitter, Youtube, hingga pesan instan seperti Line, Whatsapp, WeChat, dan BBM. Remaja Indonesia dapat dikatakan sangat mendominasi jumlah pengguna layanan internet. Hasil riset yang dilakukan Sekolah Tinggi Sandi Negara (STSN) Indonesia bersama Yahoo menunjukkan, kalangan remaja usia 15-19 tahun mendominasi pengguna internet di Indonesia (64\%). Pesatnya perkembangan dunia online ini mulai dilirik sebagai peluang emas oleh berbagai kalangan diataranya kalangan penggiat pendidikan.

Media sosial adalah sarana media online yang digunakan agar mudah berpartisipasi, berbagi, menciptakan isi meliputi blog, jejaring sosial, wiki, forum, dan dunia virtual. Andreas Kaplan dan Michael Haenlein mendefinisikan media sosial sebagai kelompok aplikasi berbasis internet yang membangun teknologi eb 2.0 dan dasar ideologi serta yang memungkinkan penciptaan dan pertukaran user-generated content.

Sosial media adalah sebuah media online membantu individu dalam mendapatkan dan menyampaikan informasi. Melalui sosial media dapat dimanfaatkan untuk sarana berbisnis dan dapat membentuk komunitas. Di era digital sekarang ini tidak sedikit komunitas yang diawali dari adanya komunikasi melalui dunia maya, bahkan gerakan aksi solidaritas dan sebagainya, saat ini sangat 
banyak yang berawal dari dunia maya atau media sosial ini (Aspari, 2016:11).

Penulis akan menjabarkan secara garis besar yang dilakukan oleh dosen Bahasa Indonesia untuk meningkatkan minat belajar mahasiswa. Membentuk suasana belajar yang inovatif, kreatif, dan berdaya guna. Salah satu inovasi yang dekat dengan siswa ataupun mahasiswa, yaitu sosisal media. Melalui media pembelajaran sosial media akan memberikan sinergi baru dalam aktivitas belajar bahasa Indonesia.

\section{METODE PENELITIAN}

Metode penelitian pada tulisan ini peneliti menggunakan "metode penelitian kualitaitf”. Penelitian yang menggunakan metode kualitatif lebih mengutakan proses daripada hasil. Proses berperan penting pada penelitian kualitatif karena yang diteliti lebih jelas, jika dilakukan dalam proses pengamatan (Moleong dalam lestari, 2017:196).

Adapun sumber data dalam penelitian ini adalah video di YouTube hasil tugas pelajaran bahasa Indonesia dan wawancara kepada mahasiswa. Pendekatan yang digunakan adalah kualitatif, dengan data berupa video di YouTube hasil tugas mempraktikkan bahasa lisan sesuai kaidah bahasa Indonesia. Penelitian kualitatif lebih fokus pada proses penghayatan terhadap hubungan antar konsep yang di kaji secara empiris. Teknik pengumpulan data yang dipergunakan dalam penelitian ini, yaitu menyimak video di YouTube dan membaca komentar-komentarnya, jumlah like, jumlah video di tonton oleh warganet, dan wawancara mahasiswa. Teknik yang dipergunakan untuk mengolah data penelitian dengan cara menyimak, menyeleksi data, menganalisis, dan menelaah data, menyimpulkan hasil.

\section{HASIL DAN PEMBAHASAN}

PEMANFAATAN SOSIAL MEDIA DALAM PEMBELAJARAN

Pemanfaatan sosial media dalam pembelajaran di kelas perlu dilakukan karena pada era globalisasi mahasiswa tidak lepas dengan sosmed. Memanfaatkan sosmed seperti facebook untuk mengakses media pembelaran sudah dilakukan sejak awal dikenal oleh warganet. Pro dan kontranya penggunaan facebook dijelaskan oleh Couillard, C. (2009). Pilgrim \& Bledsoe (2011) menjelaskan bahwa kekuatan dari sosial media pada era teknologi canggih sangat luar biasa diminati oleh kalangan muda khususnya. Jadi sosial media sangat efektif jika dapat dimanfaatkan sebagai media pembelajaran.

Keunggulan menggunakan sarana sosial media sebagai media pembelajaran terletak pada aspek interaksi dan berbagi infomasi yang lebih luas (Selwyn, 2009). Contoh pemanfaatan seperti Facebook untuk pendidikan tinggi dikemukakan oleh 
Ku, Pei-Yi dkk (2012), mereka memanfaatkan facebook sebagai media pembelajaran untuk siswa bidang ilmu komputer. Hasil penelitian tersebut meningkatkan kualitas hasil kerja peserta mata kuliah. Contoh untuk pendidikan informal disampaikan oleh Erjavec (2013) yang diterapkan pada siswa sekolah dasar di Slovenia.

Pemanfaat sosial media memberikan hasil yang signifikan untuk pembelajaran mahasiswa di kampus Mohamed \& Guandasami (2014) serta Abdelazis (2015). Hal tersebut menunjukan bahwa media sosial menjadi alternatif sebagai sarana dalam proses belajar mengajar di era teknologi modern.

\section{HASIL PEMANFAATAN SOSIAL} MEDIA YOUTUBE SEBAGAI MEDIA PEMBELAJARAN DI PERGURUAN

\section{TINGGI}

Penggunaan media sosial sebagai media pembelajaran meningkatkan antusias mahasiswa untuk mempelajari dan mengerjakan tugas Bahasa Indonesia. Sosial media yang digunakan dalam penelitian, yaitu YouTube. Melalui media sosial YouTube peserta didik akan mendapatkan bahan ajar dan membuat video yang diunggah ke akun tersebut. Peserta ajar beragam ide membuat semenarik mungkin tugas-tugas yang mereka kerjakan. Melalui media sosial peserta ajar berusaha keras memberikan yang terbaik karena akan ada penilaian dari yang menyukai (like) atau tidak suka (dislike).

Langkah-langkah penggunaan Sosial media sebagai media ajar sebagai berikut.

1. Membuat akunYouTube.

2. Pengajar memilih video-video yang cocok sebagai bahan ajar untuk diunggah ke YouTube.

3. Peserta ajar diminta untuk mengikuti YouTube pembelajaran bahasa Indonesia.

4. Selain menyimak video yang diunggah oleh pengajar peserta ajar diminta untuk membuat video secara berkelompok sebagai tugas UTS.

5. Peserta ajar setelah membuat video dan diunggah ke YouTube diberikan tugas untuk analisis hasil video kelompok lain.

Seorang pengajar tidak membuat asal tema saja, tetapi ada aspek penilaian seperti berikut ini.

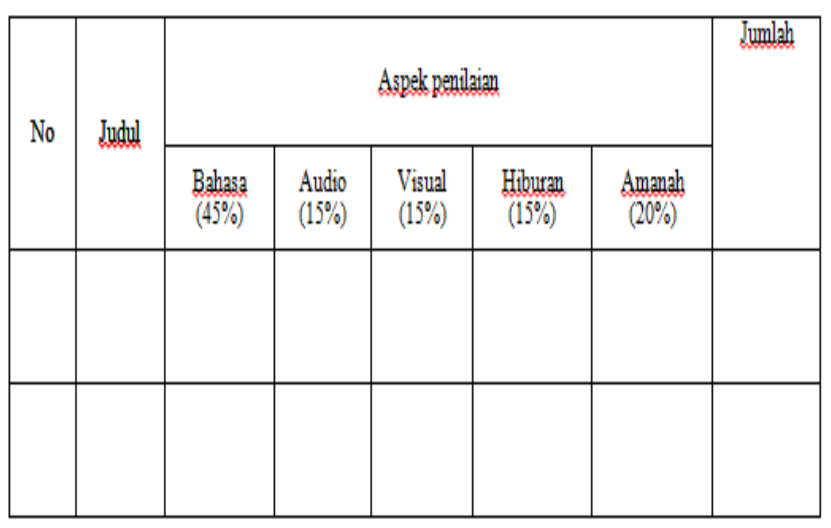

Aspek penilaian di atas diberikan kepada peserta ajar dan mereka diminta untuk lihat YouTube berisi hasil karya teman-temannya yang sudah diunggah. 
Selain itu, pengajar dapat melihat aspek penilaian dari komentar-komentar video hasil tugas peserta ajar. Peserta ajar antusias menganalisis video yang sudah diunggah. Presentasi kehadiran dan pemahaman serta antusias dalam tanya jawab meningkat ketika menggunakan media ajar YouTube.

Dosen dan mahasiswa menyepakati ada predikat video terbaik sosial media yang mendaptkan tanggapan positif, penayangan terbanyak, dan like terbaik serta tema terbaik. Penilaian dilakukan melalui hasil dari sosial media Youtube, mahasiswa, dan juri (dosen pengampu mata kuliah). Penilaian dari siswa dan dosen dilakukan ketika acara puncak, yaitu pemutaran video bersama. Sedangkan penilaian sosial media dilihat dari hasil unggahan video di Youtube disaksikan secara bersama jumlah like, komen, reviewer terbanyak dan terbaik.

Acara penilaian video Youtube selesai dilakukan. Dosen melakukan evaluasi secara lisan meminta peserta ajar untuk mengunggakapkan kesan dan pesan saat menggunakan sosial media YouTube sebagai bahan ajar. Berdasarkan hasil wawancara dari 60 mahasiswa 57 orang mengungkapkan antusias terhadap pelajaran Bahasa Indonesia karena melalui sosial media mereka dapat menampilkan hasil karya video-video yang dijadikan sebagai tugas serta lebih meningkatkan keakraban antarteman. Sedangkan 3 orang memberikan tanggapan sama seperti sebelumnya tidak ada perubahan. Peserta ajar juga menyampaikan bahwa penggunaan sosial media menumbuhkan rasa cinta terhadap bahasa Indonesia dan ingin belajar lebih baik dalam penggunaan bahasa yang baik dan benar. Selama ini peserta ajar berpikir jika bahasa Indonesia yang baik dan benar itu sesuai kaidah kebahasaan, akan tetapi ketika dijelaskan dan dipraktikkan ada kesalahan persepsi. Bahasa Indonesia yang baik dan benar, yaitu sesuai situasi penutur dan mitra tutur. Pembuatan video yang diunggah keYouTube membuat peserta ajar benar-benar harus belajar menggunakan bahasa Indonesia dan menimbulkan rasa ingin tahu konteks yang benar dalam berbahasa secara lisan. Selain itu, video yang diunggah akan dibuat dengan menarik agar mendapatkan komentar dan like yang banyak.

Pemanfaat media sosial atau sosial media sebagai bahan ajar mempunyai efek positif dalam proses belajar-mengajar di dalam dan di luar kelas. Media sosial tidak lepas dari kehidupan sehari-hari untuk kalangan remaja. Penggunaan media sosial membuat pandangan positif bahwa bahasa Indonesia bukanlah pelajaran yang membosankan tetapi, sangat mengasyikan bahkan membentuk karakter sosial dan kerjasama antar peserta ajar. Oleh karena itu, media sosial dapat menjadi media ajar untuk meningkatkan minat mahasiswa 
dalam pembelajaran bahasa Indonesia.

\section{SIMPULAN}

Mata kuliah bahasa Indonesia berperan penting untuk perkembangan emosional, sosial, dan intelektual mahasiswa di perguraun tinggi negeri maupun swasta. Pembelajaran bahasa Indonesia diharapkan dapat membantu peserta didik untuk membentuk karakter berbahasa sopan, budaya, mengemukakan pendapat dengan baik, dan meningkatkan kemampuan analisis serta imajinatif. Pembelajaran bahasa Indonesia memikliki problematika terbesar, yaitu kurangnya kreativitas metode dan media ajar sehingga membuat peserta didik jenuh mengikuti proses belajar-mengajar di kelas. Pembaruan media sangat penting di lakukan oleh pengajar. Media ajar yang digunakan harus erat dengan kehidupan sehari-hari peserta didik seperti media sosial. Belajar, ngobrol santai dengan keluarga sering menggunakan media sosial. Saat ini media sosial sudah menjadi bagian dari kehidupan masyarakat modern. Kebiasaan menggunakan media sosial ini secara tidak langsung dapat menjadikan penggunanya mengakses informasi dan mempelajari informasi yang diaksesnya, sehingga tidak heran jika saat ini perekembangan dan penyebaran bahasa berjalan dengan sangat cepat. Era digital ini menandai bahwa saat ini masyarakat sudah menjadi masyarakat yang modern.

\section{DAFTAR PUSTAKA}

Amri, Sofan. 2013. Pengembangan dan Model Pembelajaran dalam Kurikulum 2013. Jakarta: Prestasi Pustaka Publisher.

Couillard, C. (2009). Facebook: The Pros and Cons of use in Education. Thesis, University of Wisconsin-Stout: tidak diterbitkan.

Danim, S. 2002. Inovasi Pendidikan, dalam Upaya Peningkatan Profesionalisme Tenaga Kependidikan. Bandung: Penerbit Pustaka Setia.

Erjavec, K. (2013). Informal Learning through Facebook among Slovenian Pupils, Scientific Journal of Media Education, 21:117-126.

Ku, Pei-Yi, Lin, Yu-Tzu \& Tsai, Yu-Hsin. 2012. Social-Media-Assisted Learning: A Case Study of Teaching Computer Science on Facebook, International Journal of e-Education, $e$-Business, e-Management and $e$ Learning, 2(3):262-265.

Lestari, Erma. (2017). Representasi Wujud Budaya di Masyarakat Multikultural dalam Novel Burung-burung Rantau Karya Y.B Mangunwijaya. Kembara Jurnal Keilmuan Bahasa, Sastra, dan Pengajarannya, 1 Nomor 196-209.

Madge, C., Meek, J., Wellens, J. \& Hooley, T. (2009), Facebook, social integration and informal learning at university: 'It is more for socialising and talking to friends about work than for actually doing work", Learning, 
Media and Technology, 34(2):141 — 155.

Mohamed, M. \& Guandasami, W. (2014). The Influence of Peer-to-Peer Social Networks and Computer Supported Collaborative Learning (CSCL) in Mathematics, Proceeding of the International Conference on Computing Technology and Information Management, Dubai.

Pilgrim, J., \& Bledsoe, C. 2011. Learning through facebook: A potential tool for educators. Delta Kappa Gamma Bulletin, 78(1): 38-42.

Rozhana, K,M \& Sari, N,K. 2018. Pelaksanaan Pendidikan Karakter dalam Proses Pembelajaran untuk Menumbuhkan Sikap Nasionalisme. Prosiding Seminar Nasional Pengembangan Profesionalisme Dosen dan Guru Indonesia, Volume 2 (Online) (https://semnas.unikama.ac.id/fip/un duhan/2018/47851298.pdf), di akses 21 Juni 2019.

Rusyana, Yus. 1984. Bahasa dan Sastra dalam Gamitan Pendidikan. Bandung: Diponegoro.

Selwyn, N. (2009). Faceworking: exploring students' education-related use of Facebook. Learning Media and Technology, 34(2), 157-174. 